\title{
Invasive acacias experience higher ant seed removal rates at the invasion edges
}

\author{
D. Montesinos, S. Castro, and S. Rodríguez-Echeverría \\ CFE, Center for Functional Ecology, University of Coimbra, P.O. Box 3046, 3001-401, Coimbra, Portugal \\ Correspondence to: D. Montesinos (danimontesinos@gmail.com)
}

Received: 5 March 2012 - Revised: 21 May 2012 - Accepted: 23 May 2012 - Published: 13 June 2012

\begin{abstract}
Seed dispersal is a key process for the invasion of new areas by exotic species. Introduced plants often take advantage of native generalist dispersers. Australian acacias are primarily dispersed by ants in their native range and produce seeds bearing a protein and lipid rich reward for ant mutualists (elaiosome). Nevertheless, the role of myrmecochory in the expansion of Australian acacias in European invaded areas is still not clear. We selected one European population of Acacia dealbata and another of A. longifolia and offered elaiosome-bearing and elaiosome-removed seeds to local ant communities. For each species, seeds were offered both in high-density acacia stands and in low-density invasion edges. For both acacia species, seed removal was significantly higher at the low-density edges. For A. longifolia, manual elimination of elaiosomes reduced the chance of seed removal by $80 \%$ in the low-density edges, whereas it made no difference on the high-density stands. For $A$. dealbata, the absence of elaiosome reduced seed removal rate by $52 \%$, independently of the acacia density. Our data suggests that invasive acacias have found effective ant seed dispersers in Europe and that the importance of such dispersers is higher at the invasion edges.
\end{abstract}

\section{Introduction}

The establishment of successful key mutualisms in invaded ecosystems has been suggested as an essential mechanism for the survival, spread and establishment of invasive exotic plants (Richardson et al., 2000; Traveset and Richardson, 2006). Plants are involved in many forms of mutualisms, for nutrient acquisition, pollination or seed dispersal, which are critical to their ecological success and, therefore, might be crucial for the invasion of new areas (Davidson and Morton, 1984; Auld, 1986; Traveset et al., 2000; Richardson et al., 2000; Whitney, 2002; Jensen and Six, 2006). In some cases exotic plants only become invasive after the introduction of mutualists from their native range (Richardson et al., 2000) and, theoretically, plants that are involved in very specific mutualistic interactions should fail to colonize new habitats where those organisms are absent. However, plants introduced to new geographical regions can forge totally novel combinations by plugging into the native mutualistic networks, or associating with other exotic species (Simberloff and Holle, 1999; Richardson et al., 2000) and the increasing degradation of ecosystems worldwide leads to an increasing abundance of generalist mutualistic partners that can trigger the invasion by exotic species. For instance, invasive species have been found to be dispersed in their non-native ranges both by native and non-native ant species (Smith, 1989; Bossard, 1991; Jensen and Six, 2006; Alba-Lynn and Henk, 2010).

Recent studies indicate that invasive species can show differences between the expanding invasion edges and mature invaded areas (Phillips et al., 2006, 2007; Lankau et al., 2009). Plant invasions lead to changes in habitat structure, morphology and food availability, which often result in important changes in the native animal community (French and Major, 2001; Traveset and Richardson, 2006). For instance the replacement of New Zealand native Kunzea ericoides by non-native Ulex europaeus led to changes on vegetation which resulted in significant changes in the bird and small mammal seed-dispersing community (Williams and Karl, 2002). Such changes can lead to a reduction in the frequency of dispersal of native plants as the invasion process progresses (Sallabanks, 1993). 
Taking into account the area occupied and its impacts on native ecosystems, two woody Australian species can be considered as the most problematic and widespread invasive exotic plants in Portugal: Acacia dealbata Link and A. longifolia (Andr.) Willd. (Almeida and Freitas, 2006; Lorenzo et al., 2010a; Marchante et al., 2010). In spite of their fast expansion and ecological impacts in the invaded areas, little is known about the invasive dynamics of these Australian acacias in Portugal. Enemy release might partially explain their invasive expansion, but acacias are involved in other biotic interactions, such as belowground mutualisms (RodríguezEcheverría et al., 2009, 2010), essential for the colonization of new areas and for long-term establishment of viable populations. Acacias present elaiosome-bearing seeds and, in their native range, seeds of Australian acacias are primarily dispersed by ants. Ants also play an important role on acacia invasions in South Africa (Holmes, 1990; French and Major, 2001). Their successful expansion in Southern Europe suggests that they could have found effective ant seed dispersers, but to date there is no data on the importance of ants on acacia seed dispersal out of Australia and South Africa.

The objective of this work was to determine the role of ant mutualists in the expansion of A. dealbata and A. longifolia. Our general working hypotheses were (a) Australian acacias need to find compatible ant mutualists in the invaded range to disperse their seeds efficiently; (b) acacia invasions change habitat structure and seed removal rates by ants; and (c) the presence of elaiosomes plays a major role on seed dispersal. To address these hypotheses we studied seed removal rates by ants and the relative importance of the presence of elaiosomes to the strength of such interactions, by experimentally offering elaiosome-bearing and elaiosome-removed seeds to ants at both high-density acacia stands and low-density invasion edges of expanding acacia populations.

\section{Materials and methods}

\subsection{Study species}

Acacia dealbata and A. longifolia were intentionally introduced in Portugal during the first half of the 20th century for forestry, soil stabilization and gardening purposes (Almeida and Freitas, 2006; Lorenzo et al., 2010a). Their invasive expansion has been documented mainly in the last $10 \mathrm{yr}$, and nowadays they are widely distributed and are the dominant species in many areas of Portugal (Lorenzo et al., 2010b; Marchante et al., 2010; Gibson et al., 2011). Acacia dealbata is the most aggressive invader of inland Portugal, grows in mountain ranges and road sides (Almeida and Freitas, 2006; Lorenzo et al., 2010a). It is listed as one of the worst invasive species in Europe, and is also an invader in the USA and South Africa (Lorenzo et al., 2010a). Acacia longifolia invades coastal sand dunes, being more abundant in the central and northern coast of Portugal (RodríguezEcheverría et al., 2009; Lorenzo et al., 2010a). It has been described as invasive species in other European countries, South Africa and New Zealand (Lorenzo et al., 2010a). Both species establish complex mutualistic interactions in their native range, and depend on these mutualisms for the successful colonization of new areas (Berg, 1975; O'Dowd and Gill, 1986; Rodríguez-Echeverría, 2010, 2011; Gibson et al., 2011). Other common aspects of their biology are fast growth rates, drought resistance, early flowering and asynchrony in flower development (Gibson et al., 2011). Their lifespan is about 20-50 yr for A. dealbata and $30 \mathrm{yr}$ for A. longifolia (Richardson et al., 2011).

\subsection{Sites}

The role of ants in dispersing seeds of Acacia longifolia was studied in Tocha (40.328420, -8.807237; datum WSG84), a coastal dune system on the central-northern coast of Portugal. The climate is Mediterranean with an Atlantic influence. Mean annual precipitation is $948 \mathrm{~mm}$ and mean monthly temperatures range from $10.2^{\circ} \mathrm{C}$ in January to $20.2^{\circ} \mathrm{C}$ in June with an annual mean of $16.2^{\circ} \mathrm{C}$. The area consists of a wellpreserved dune system with foredunes, primary dunes, interdune slacks and secondary dunes. The native vegetation is characterized by herbs, small shrubs and few trees and contains characteristic coastal sand dune species such as Ammophila arenaria (L.) Link, Corema album (L.) D.Don ex Steud., Elymus farctus (Viv.) Runemark ex Melderis, Euphorbia paralias L. and Otanthus maritimus (L.) Hoffmanns. \& Link.

For A. dealbata, the study site was located in Lousã (40.102568, -8.233698), a mountainous area $70 \mathrm{~km}$ inland from Tocha. Climate is Mediterranean with Atlantic influence. Mean annual precipitation is $752 \mathrm{~mm}$ and mean monthly temperatures range from $3{ }^{\circ} \mathrm{C}$ in January to $17.6^{\circ} \mathrm{C}$ in August with an annual mean of $9.2^{\circ} \mathrm{C}$. Native vegetation in this area is a mixed oak forest dominated by Quercus canariensis Willd., Q. robur L., Castanea sativa Mill. and Pinus pinaster Aiton, with an understorey dominated by several Erica species and Pterospartum tridentatum K.Koch.

Within each site, we selected two areas, one corresponding to a typical colonization edge (low acacia density), and another corresponding with a mature stand (high acacia density). These areas presented differences in acacia tree density of one order of magnitude ( 0.13 vs. 1.00 trees $^{-2}$ for $A$. longifolia and 0.30 vs. 5.40 trees $\mathrm{m}^{-2}$ for $A$. dealbata). Tree density was estimated based on three transects of $10 \times 1 \mathrm{~m}$ randomly distributed across each area.

\subsection{Seed removal by ants}

To account for the role of elaiosome on the strength of ant mutualistic interactions we offered, on each area (high and low density) and each location (Tocha and Lousã), two sets of ten Petri dishes. Each Petri dish in a set contained either 20 freshly harvested seeds or 20 seeds without elaiosome. 
Elaiosomes were manually removed one week before the setup of the experiment. Petri dishes were covered with a lid and had three $5 \mathrm{~mm}$ wide holes to allow the transit of ants while impeding seed removal by bigger animals. Lids were secured with a little rock to avoid disturbance by wind. All Petri dishes were placed randomly across each area and location simultaneously with the seed dispersal peak (1011 July 2011). The final number of seeds left on each plate was recorded after two weeks to allow for a representative sampling of the seed removal rates experienced by seeds naturally dispersed into the field.

\subsection{Statistics}

To assess the effect of acacia tree density and elaiosome presence/absence (fixed factors) on the rate of seed removal by ants, we used GLM tests for each acacia species. The analysis was made using SPSS 19 software (Norusis, 2002).

\section{Results}

\section{Seed removal by ants}

For A. longifolia (Tocha), the low-density edges presented significantly higher seed removal rates than the high-density stands (density $F=17.5, \mathrm{~d} f=1 ; p<0.001$ ). The presence of elaiosome made no difference on the rate of seed removal on high-density stands. However, on the low-density edges, elaiosome bearing seeds had a five times higher seed removal rate than non-elaiosome bearing seeds (elaiosome $F=11.1$; $\mathrm{d} f=1 ; p=0.002$; interaction density $\times$ elaiosome $F=13.4$; $\mathrm{d} f=1 ; p=0.001$ ) (Fig. 1).

For A. dealbata (Lousã), the low-density edges also presented significantly higher seed removal rates than the highdensity stands (density $F=44.1 ; \mathrm{d} f=1 ; p=<0.001$ ). Elaiosome bearing seeds were removed twice as much as nonelaiosome bearing seeds at both tree densities (elaiosome $F=12.2 ; \mathrm{d} f=1 ; p=0.001 ;$ interaction density $\times$ elaiosome $F=2.88 ; \mathrm{d} f=1 ; p=0.098$ ) (Fig. 1).

\section{Discussion}

Plants introduced into new geographical ranges usually encounter few dispersal barriers (Traveset and Richardson, 2006) and acacias are not an exception. However, we found interesting differences in the intensity of seed removal by ants depending on acacia density and elaiosome presence. For both acacia species, seed removal was significantly higher at the low-density invasion edges. Seeds without elaiosome were removed significantly less often, but differences were observed between acacia species and populations. For A. longifolia, the absence of elaiosome reduced the chance of removal by $80 \%$ in the low-density edges, whereas it made no difference on the high-density stands. For A. deal-
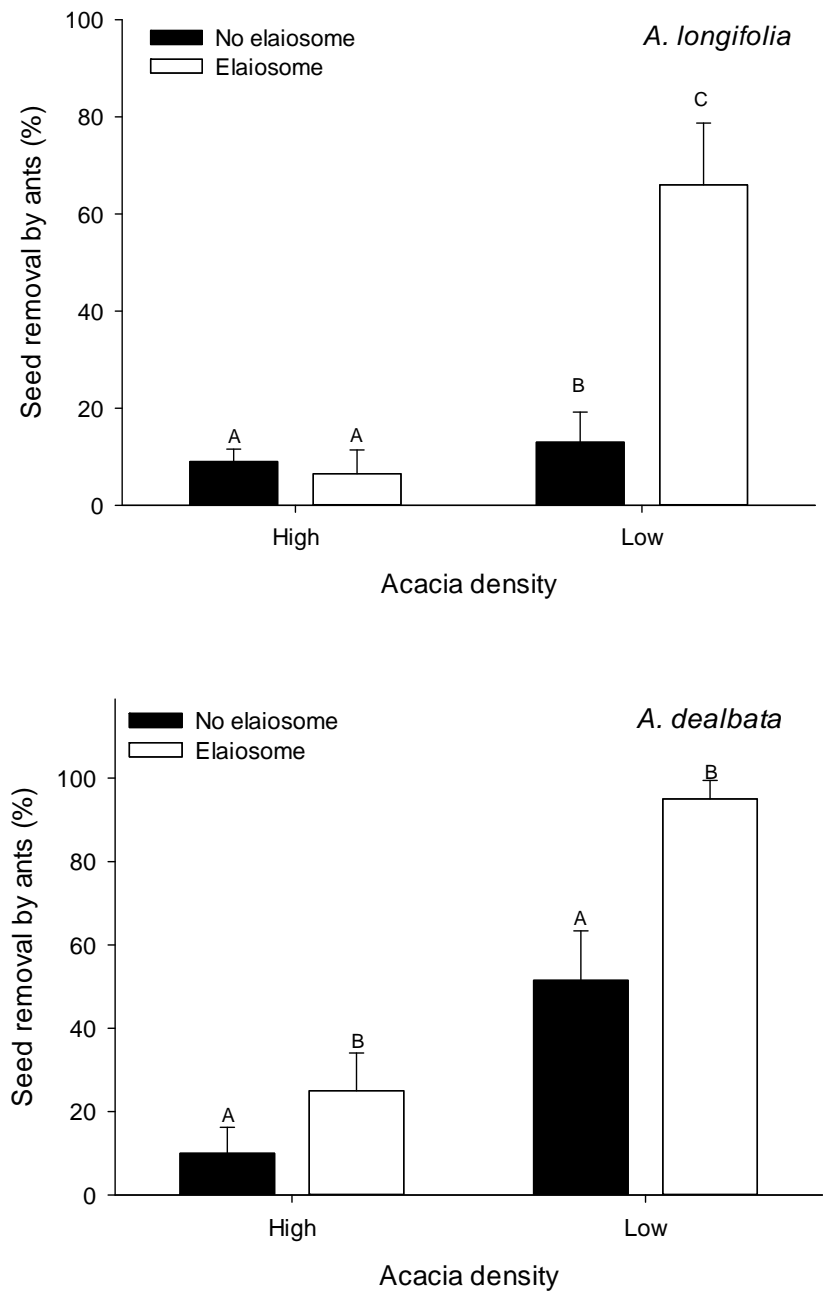

Figure 1. Seed removal by ants (\%) on high-density mature stands and low-density invasion edges of Acacia longifolia (above) and A. dealbata (below) for elaiosome bearing (white bars) and elaiosome absent seeds (black bars). Different letters indicate statistically significant differences.

bata, the absence of elaiosome reduced the removal rate by $52 \%$, independently of the acacia density.

The presence of elaiosomes is key in the successful establishment of mutualisms between plants and ants, and thus, on seed dispersal processes (Gorb and Gorb, 1999; Traveset et al., 2000; Lengyel et al., 2009; Fokuhl et al., 2012). Myrmecochory is present in at least 11000 species, representing $4.5 \%$ of all plant species (Lengyel et al., 2010). Although up to $90 \%$ of myrmecochorous plant species are native of the Southern Hemisphere, the remaining $10 \%$ guarantees the presence in the Northern Hemisphere of ants which have the potential to disperse the seeds of myrmecochorous plants introduced from the South (Gómez and Espadaler, 1998; Lorenzo et al., 2010a; Lengyel et al., 2010). Consequently, elaiosome presence has been reported to be very important for some plant invasions (Pemberton and Irving, 
1990; Richardson et al., 2000); therefore, it is not surprising that its presence has such an important effect on acacia seed removal rates. However, the comparison between seed removal rates for elaiosome-bearing and elaiosome-absent seeds offers interesting information. The fate of the seeds removed from our experiments is unclear, since ants can be either beneficial seed dispersers or granivorous predators (Traveset et al., 2000). Nevertheless, elaiosome-absent seeds are likely to be removed only by granivore predators, while elaiosome-bearing seeds will also attract mutualistic ant seed dispersers interested mainly in the nutritious elaiosome (e.g. Bas et al., 2009). The dramatic increase in seed removal of elaiosome-bearing seeds suggest that an important part of the elaiosome-bearing seeds removed at the invasion edges were effectively dispersed (as opposed to preyed).

Differences in removal rates between different density areas could be explained by differences in the composition and abundance of the ant community, which is known to be strongly influenced by changes in the habitat produced by the invaders (Traveset and Richardson, 2006). As the acacia invasion matures and the habitat changes from open shrubs to dense woody stands, there is a significant reduction in seed removal rates, and in the importance of elaiosome presence for seed removal. French and Major (2001) found that, in the South African Fynbos, pristine native areas hosted richer ant assemblages, while the presence of Acacia saligna at highdensities implied poorer ant assemblages. We do not have data on the ant assemblages present on our high and low density acacia stands. However, the differences detected in seed removal rates and a few preliminary observations (Montesinos, personal observation) suggest that differences in ant assemblages might be found. Future research should fully describe ant community composition at different invasion densities and relate it to seed removal rates both for invasive acacias and for the remaining native plant community.

Acknowledgements. Authors want to thank Klerton Xavier for help with fieldwork. Research was funded by the project MUTUALNET (PTDC/BIA-BEC/103507/2008) from the Portuguese Fundação para a Ciência e a Tecnologia-FCT. FCT also financed the post-doctoral grants of DM (SFRH/BPD/72595/2010) and SC (SFRH/BPD/41200/2007).

Edited by: F. Pugnaire

Reviewed by: two anonymous referees

\section{References}

Alba-Lynn, C. and Henk, S.: Potential for ants and vertebrate predators to shape seed-dispersal dynamics of the invasive thistles Cirsium arvense and Carduus nutans in their introduced range (North America), Plant Ecol., 210, 291-301, 2010.

Almeida, J. D. D. and Freitas, H.: Exotic naturalized flora of continental Portugal - A reassessment, Botanica Complutensis, 30, 117-130, 2006.
Auld, T. D.: Population dynamics of the shrub Acacia suaveolens (Sm.) Willd.: Fire and the transition to seedlings, Austral Ecol., 11, 373-385, 1986.

Bas, J. M., Oliveras, J., and Gómez, C.: Myrmecochory and shortterm seed fate in Rhamnus alaternus: Ant species and seed characteristics, Acta Oecol., 35, 380-384, 2009.

Berg, R.: Myrmecochorous plants in Australia and their dispersal by ants, Aust. J. Bot., 23, 475-508, 1975.

Bossard, C. C.: The role of habitat disturbance, seed predation and ant dispersal on establishment of the exotic shrub Cytisus scoparius in California, Am. Midl. Nat., 126, 1-13, 1991.

Davidson, D. W. and Morton, S. R.: Dispersal adaptations of some Acacia species in the autralian arid zone, Ecology, 65, 10381051, 1984.

Fokuhl, G., Heinze, J., and Poschlod, P.: Myrmecochory by small ants - Beneficial effects through elaiosome nutrition and seed dispersal, Acta Oecol., 38, 71-76, 2012.

French, K. and Major, R. E.: Effect of an exotic Acacia (Fabaceae) on ant assemblages in South African fynbos, Austral Ecol., 26, 303-310, 2001.

Gibson, M. R., Richardson, D. M., Marchante, E., Marchante, H., Rodger, J. G., Stone, G. N., Byrne, M., Fuentes-Ramírez, A., George, N., Harris, C., Johnson, S. D., Roux, J. J. L., Miller, J. T., Murphy, D. J., Pauw, A., Prescott, M. N., Wandrag, E. M., and Wilson, J. R. U.: Reproductive biology of Australian acacias: important mediator of invasiveness?, Divers. Distrib., 17, 911-933, 2011.

Gorb, E. V. and Gorb, S. N.: Dropping rates of elaiosome-bearing seeds during transport by ants (Formica polyctena Foerst.): Implications for distance dispersal, Acta Oecol., 20, 509-518, 1999.

Gómez, C. and Espadaler, X.: Myrmecochorous dispersal distances: a world survey, J. Biogeogr., 25, 573-580, 1998.

Holmes, P. M.: Dispersal and predation in alien Acacia, Oecologia, 83, 288-290, 1990.

Jensen, J. M. and Six, D. L.: Myrmecochory of the Exotic Plant, Centaurea maculosa?: A Potential Mechanism Enhancing Invasiveness, Environ. Entomol., 35, 326-331, 2006.

Lankau, R. A., Nuzzo, V., Spyreas, G., and Davis, A. S.: Evolutionary limits ameliorate the negative impact of an invasive plant, P. Natl. Acad. Sci. USA, 106, 15362-15367, 2009.

Lengyel, S., Gove, A. D., Latimer, A. M., Majer, J. D., and Dunn, R. R.: Ants sow the seeds of global diversification in flowering plants, PLoS ONE, 4, e5480, doi:10.1371/journal.pone.0005480, 2009.

Lengyel, S., Gove, A. D., Latimer, A. M., Majer, J. D., and Dunn, R. R.: Convergent evolution of seed dispersal by ants, and phylogeny and biogeography in flowering plants: A global survey, Perspect. Plant Ecol., 12, 43-55, 2010.

Lorenzo, P., González, L., and Reigosa, M. J.: The genus Acacia as invader: the characteristic case of Acacia dealbata Link in Europe, Ann. For. Sci., 67, 101-101, 2010a.

Lorenzo, P., Palomera-Pérez, A., Reigosa, M. J., and González, L.: Allelopathic interference of invasive Acacia dealbata Link on the physiological parameters of native understory species, Plant Ecol., 212, 403-412, 2010b.

Marchante, H., Freitas, H., and Hoffmann, J. H.: Seed ecology of an invasive alien species, Acacia longifolia (Fabaceae), in Portuguese dune ecosystems, Am. J. Bot., 97, 1780-1790, 2010. 
Norusis, M. J.: SPSS 11.0: guide to data analysis, Prentice Hall, Upper Saddle River, NJ, 2002.

O'Dowd, D. J. and Gill, A. M.: Seed dispersal syndromes in Australian Acacia, in: Seed dispersal, edited by: Murray, D., Academic Press, 87-121, 1986.

Pemberton, R. W. and Irving, D. W.: Elaiosomes on Weed Seeds and the Potential for Myrmecochory in Naturalized Plants, Weed Sci., 38, 615-619, 1990.

Phillips, B. L., Brown, G. P., Webb, J. K., and Shine, R.: Invasion and the evolution of speed in toads, Nature, 439, p. 803, 2006.

Phillips, B. L., Brown, G. P., Greenlees, M., Webb, J. K., and Shine, R.: Rapid expansion of the cane toad (Bufo marinus) invasion front in tropical Australia, Austral Ecol., 32, 169-176, 2007.

Richardson, D. M., Allsopp, N., D’Antonio, C. M., Milton, S. J., and Rejmánek, M.: Plant invasions - the role of mutualisms, Biol. Rev., 75, 65-93, 2000.

Richardson, D. M., Carruthers, J., Hui, C., Impson, F. a. C., Miller, J. T., Robertson, M. P., Rouget, M., Le Roux, J. J., and Wilson, J. R. U.: Human-mediated introductions of Australian acacias a global experiment in biogeography, Divers. Distrib., 17, 771787, 2011.

Rodríguez-Echeverría, S.: Rhizobial hitchhikers from Down Under: invasional meltdown in a plant-bacteria mutualism?, J. Biogeogr., 37, 1611-1622, 2010.

Rodríguez-Echeverría, S., Crisóstomo, J. A., Nabais, C., and Freitas, H.: Belowground mutualists and the invasive ability of Acacia longifolia in coastal dunes of Portugal, Biol. Invasions, 11, 651-661, 2009.
Rodríguez-Echeverría, S., Le Roux, J. J., Crisóstomo, J. a., and Ndlovu, J.: Jack-of-all-trades and master of many? How does associated rhizobial diversity influence the colonization success of Australian Acacia species?, Divers. Distrib., 17, 946-957, 2011.

Sallabanks, S.: Fruiting plant attractiveness to avian seed dispersers: native vs. invasive Crataegus in Western Oregon, Madroño, 40, 108-116, 1993.

Simberloff, D. and Holle, B. V.: Positive interactions of nonindigenous species: invasional meltdown?, Biol. Invasions, 1, 21-32, 1999.

Smith, J. M. B.: An example of ant-assisted plant invasion, Austral Ecol., 14, 247-250, 1989.

Traveset, A. and Richardson, D. M.: Biological invasions as disruptors of plant reproductive mutualisms, Trends Ecol. Evol., 21, 208-216, 2006.

Traveset, A., Fenner, M., and Willson, M. F.: The ecology of seed dispersal, in: Seeds: The ecology of regeneration in plant communities, 2nd Edn., edited by: Fenner, M., CAB International, Wallingford, UK, 85-110, 2000.

Whitney, K. D.: Dispersal for distance? Acacia ligulata seeds and meat ants Iridomyrmex viridiaeneus, Austral Ecol., 27, 589-595, 2002.

Williams, P. A. and Karl, B. J.: Birds and small mammals in kanuka (Kunzea ericoides) and gorse (Ulex europaeus) scrub and the resulting seed rain and seedling dynamics, New Zeal. J. Ecol., 26, 31-41, 2002. 